\title{
Tribological Assessment of Aluminum Cylinder Material for Piston Compressors in Trucks and Buses Brake Systems
}

\author{
Saša MILOJEVIĆ*, Dragan DŽUNIĆ, Dejan MARIĆ, Tomáš SKRÚCANÝ, Slobodan MITROVIĆ, Radivoje PEŠIĆ
}

\begin{abstract}
Applying new technologies to reduce friction and wear in vehicles and equipment can minimize mechanical losses. This reduces power loss in internal combustion engines and reduces fuel consumption and emissions. Consumption of fuel energy can be reduced by the use of light metals, for example aluminum alloy, to produce vehicles and their aggregates and parts. In this case, the problem is poor tribological properties of those light weight metals, as well as the lower strength compared to the cast iron construction. For tribology research purposes, the contact surface of the aluminum cylinder of an experimental piston air compressor is reinforced with inserts of cast iron. The results of tribology research of the composite material are presented in the paper, explaining how parameters such as the sliding speed, contact time and contact area influence friction and wear of the material in relative tribological contacts, under constant normal force. The test procedures were performed on the ball-on-plate $\mathrm{CSM}^{\circledR}$ nanotribometer, in linear reciprocating sliding conditions with no lubricant. Material composition of the samples was determined using the Energy-Dispersive Spectroscopy. All measurements were realized at the Faculty of Engineering, University of Kragujevac.
\end{abstract}

Keywords: aluminum cylinder; friction and wear; piston compressor; tribological reinforcements; tribometer

\section{INTRODUCTION}

In domain of heavy-duty vehicles, the proposed level for reduction of carbon dioxide $\left(\mathrm{CO}_{2}\right)$ emission between 25 and $30 \%$ and nitrogen oxides $\left(\mathrm{NO}_{\mathrm{x}}\right)$ of up to $90 \%$ can be realized with serious technical innovations on vehicles and power systems [1-3].

The set goals could be achieved by applying modern technologies in order to optimize combustion and tribological processes [4-10].

According to the above, main focus during optimization of internal combustion engines (ICE) is friction reduction, resulting in lower fuel consumption and exhaust emission [10-12].

Within the engines and compressors, the relative motion of piston with rings inside the cylinder liner has the largest impact on fuel consumption because of higher friction and wear. To avoid ruin of function during time, these mechanical parts from metal alloys could be manufactured of materials of high hardness for friction reduction and wear protection [13-15].

From the other side, the fuel consumption is reduced also if we use aluminum as a lighter material for designing of vehicles, engines and equipment. In that case, the main problem is lower hardness of material resulting in intense wear during tribological contact [16-19].

By modification of surfaces which are in direct contact with anti-friction coatings or by use of composite materials, we can resolve the problems related to hardness and friction and wear of aluminum parts [20-23].

Diamond-like coatings (DLC) are in use in ICE for lowering of friction and wear. Chromium nitride is in use as a coating for piston rings. This will reduce fuel consumption and therefore emission $[23,24]$.

In that way, tribological properties are greatly improved over classic honing of the cylinder with various surface textures of cylinder liner $[25,26]$.

In ICE, about a quarter of indicated power is used to overcome the friction and mechanical losses between combustion chamber and freewheel. In heavy-duty vehicles tribomechanical system of piston, rings and cylinder liner accounts up to $2 \%(8 \%$ in passenger vehicles) in fuel consumption. According to this, $10 \%$ reduction in the friction of the piston and rings reduces fuel consumption by $0,2 \%$ [27-30].

In line with the available research results, as well as with our own experience, research into variablemechanisms of engines was first initiated. We have investigated the application of gasoline and diesel engines with variable compression ratio (VCR) and multi-fuel technology $[4,9]$.

Then, tribology research in domain of ICE and piston compressors designed from lightweight materials was also performed [10].

\subsection{Data, Method and Initial Researches}

For research purposes, the bus compressor for compressed air in braking system was reconstructed. The piston compressor cylinder was designed and made of aluminum with cast iron inserts. This was necessary, since aluminum has lower hardness than cast iron.

One solution is to coat the contact surface of the cylinder with a suitable coating using a thermal spray method. This method has already been used in ICE and due to that we were starting the research with the corresponding and comparative available information. Coatings play an important role in friction and wear reduction inside ICE and valve train for example, Fig. 1 [31-33].

Regarding the first option, for the purposes of the experiment, surface of the aluminum cylinder as base material (alloy EN AlSi10Mg) was partially modified and reinforced by putting tribological reinforcements of iron arranged in the form of discrete tribological plugs or spheres (nodule), Fig. 1.

The research was initiated by the idea that the tribological contact between the piston rings and the cylinder could be pre-determined and accomplished through tribological inserts.

This is because of the realistic machining and working conditions, why it is very difficult to simulate contact between piston rings and the cylinder liner, due to the oval shape and designed grooves within the cylinders inner wall. Cylinder ovality is usually caused by wear 
phenomena and different intensity of normal forces, due to tribology contact between piston, rings and cylinder liner. As a result, the piston axis is eccentric to the cylinder axis $[34,35]$.

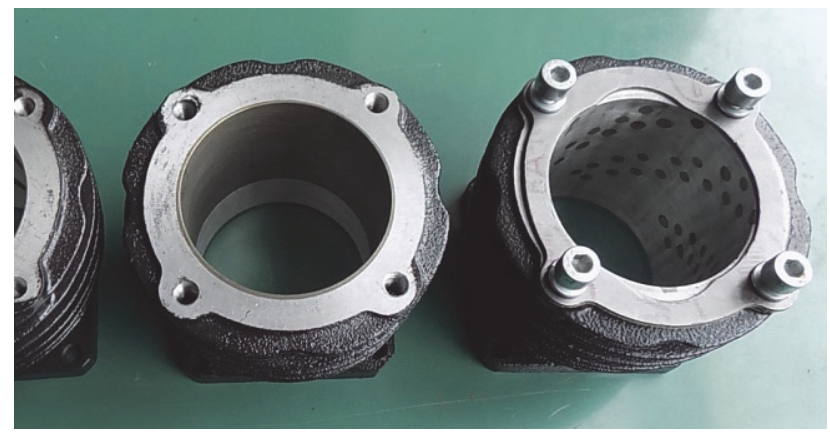

Figure 1 Photography of experimental cylinder samples. Left is cylinder coated with thermal spray method and right with reinforcements (nodules)

The above problem could be solved by applying the cylinder with inserts, Fig. 1. Proposed technology with inserts has no limitations in terms of compressor cylinder production and machining capabilities.

On the other hand, the goal is to extend the service life of the reciprocating machines as well as the reliability in exploitation.

During researches was performed tribological research of the cylinder material and reinforcements. Inside the paper one part of the results will be discussed.

After the tribological optimization of the parts of the piston group, an experimental test of the compressor on the test rig will be carried out.

\section{EXPERIMENTAL CONDITIONS AND EQUIPMENT}

Modern, computer-aided $\mathrm{CSM}^{\circledR}$ nanotribometer was used to test the aluminum, cylinder material and cast iron, material that cylinder inserts were made of (Fig. 2).

Tribological investigations were performed on the $\mathrm{CSM}^{\circledR}$ nanotribometer, with ball-on-plate contact geometry with linear reciprocating movement, in dry sliding conditions. Linear reciprocating movement was chosen in order to simulate real contact between piston rings and the cylinder. Nanotribometer normal force range is $50 \mu \mathrm{N}$ to $1 \mathrm{~N}$, with $1 \mu \mathrm{N}$ resolution, while friction force range is $10 \mu \mathrm{N}$ to $1 \mathrm{~N}$, with the same resolution. During the contact normal force remains constant. In order to simulate different sliding conditions, three different values of normal force were chosen, 0,$3 ; 0,6$ and $0,9 \mathrm{~N}$. Related to that three different values for sliding speed were 3,9 and 15 $\mathrm{mms}^{-1}$. Penetration depth measurement is very precise, with accuracy of $20 \mathrm{~nm}$.

Along with the normal and friction forces values nanotribometer obtains penetration depth value, which is related to the counter body (ball) movement along the $z$ axis. Measurement range is from $20 \mathrm{~nm}$ to $100 \mu \mathrm{m}$, with 20 $\mathrm{nm}$ resolution. Fig. 3 presents a scheme of nanotribometer cantilever, in linear reciprocating movement configuration.

Tribological tests were performed in dry sliding conditions. Normal load and sliding speed remain constant during the test.

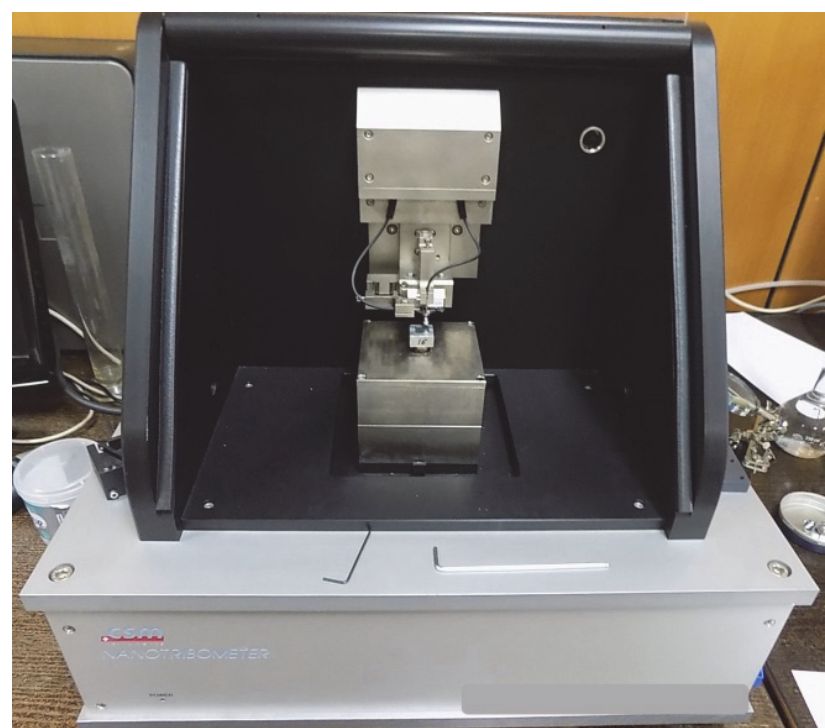

Figure 2 Photography of standard CSM ${ }^{\circledR}$ Instruments tribometer

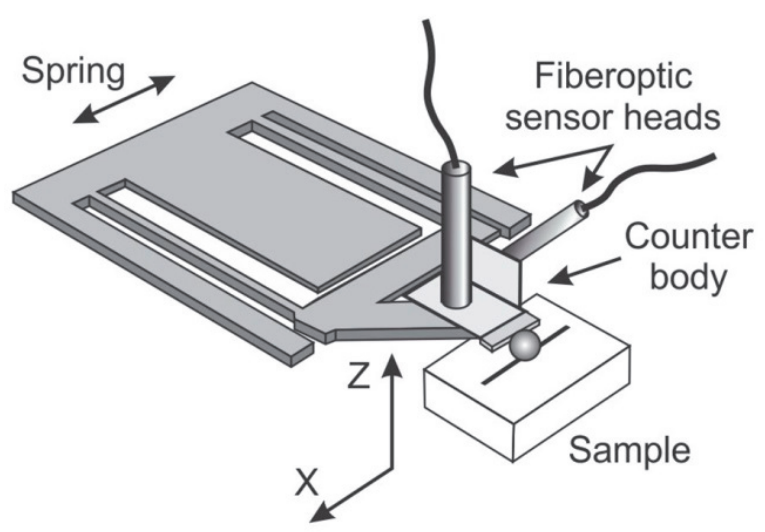

Figure 3 Module of tribometer for realization of relative sliding motion between the ball and sample of tested material

Linear reciprocating movement was chosen due to linear reciprocating movement of engine piston within the cylinder. During the tribological test normal load and sliding speed remain constant. Duration time of each test is 500 cycles at each test mode (corresponding to a sliding distance of $1 \mathrm{~m})$, with half the amplitude $(0,5 \mathrm{~mm})$ and acquisition frequency of $(50 \mathrm{~Hz})$. During testing, ambient temperature was maintained in the range $\left(21 \pm 2{ }^{\circ} \mathrm{C}\right)$, with recorded air humidity of $45 \%$. Each test was repeated at least 3 times. Counter body was 1,5 mm steel (100Cr6) ball.

Commercial software (TriboX 2.9.0) was used to record and process the data. Under each mode, after finishing, the material samples were removed from the tribometer and were photographed with an optical microscope. The wear of the sliding surface of the test material (surface layer) was estimated according to measured values of the penetration depth. Worn layers (photographed wear traces) were analyzed by using dedicated software for image processing (Infinity Analysis). Wear trace volume and wear rate were calculated for each test mode according to ASTM G133-05 method, after a sliding distance of $(1 \mathrm{~m})$ [20].

Using optical microscopes were analyzed the surfaces of the prepared specimens as well as the resulting wear 
traces. The scanning electron (SEM) microscope manufacturer is Meiji Techno, they are computer-aided and each of the microscopes is with its own illuminators and high-resolution camera.

More detailed analysis of the tested material samples was performed by using a Phenom ProX EnergyDispersive Spectroscopy (EDS).

\section{RESULTS REGARDING TRIBOLOGY RESEARCHES}

\subsection{Optical Microscopic Analysis of the Aluminum with} Cast Iron Inserts Material before Testing

Testing was performed with samples made of the piston compressor cylinder base material, (Al-Si) alloy, and on iron-based material of inserts.

Fig. 4 provides an optical representation of the microstructure of the standard material for cylinders, which could be reinforced with previously mentioned cast iron inserts. On the material surface we can see the gray phases that represent eutectic silicon $[36,37]$.

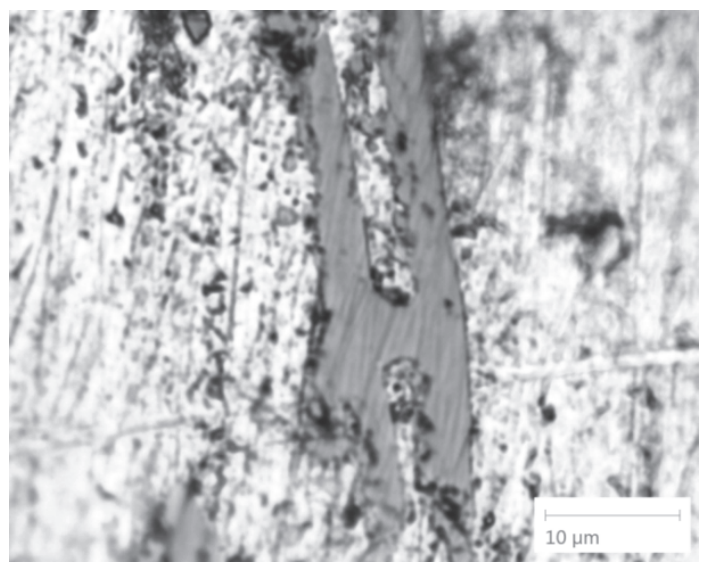

Figure 4 Optical microscopy of aluminum-silicon alloy as base cylinder material

In Fig. 5 an optical representation of the material of cast iron or iron-carbon alloy inserts as reinforcements is given. Inserts are arranged discreetly by casting within the cylinder matrix in the form of tribological plugs of spherical shape (nodules), or particles of spherical shape. By a more detailed analysis of the microstructure of the surface, it is concluded that the black lines do not represent micro cracks in the material but traces of graphite in the cast iron [38].

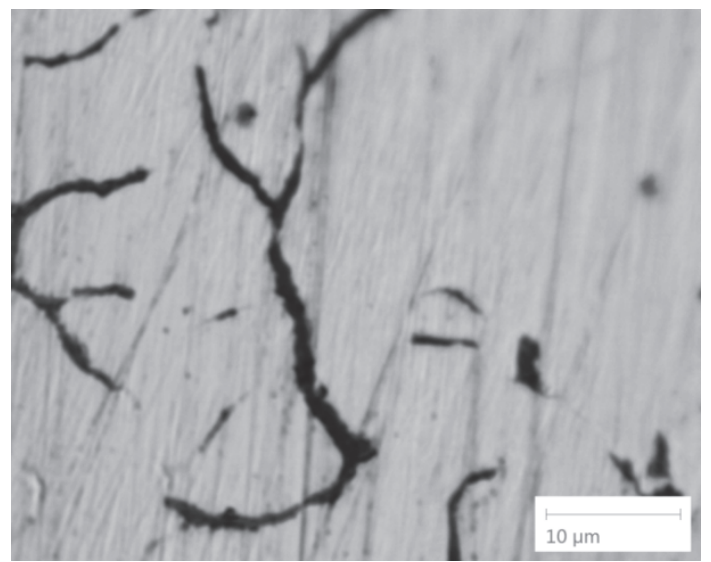

Figure 5 Optical microscopy of cast-iron alloy as material of inserts or reinforcements cylinder material.

\subsection{Determination of Coefficient of Friction and Penetration Depth of Base Material (Al-Si) Alloy}

The changes of coefficient of friction (COF) and penetration depth (PD) (on ordinates), depending on the sliding time of ball, distance and lap number (contact cycles) are presented in Fig. 6, Fig. 7 and Fig. 8. The results are for the base material in metal (Al-Si) alloy.

The results shown were obtained by examining the material on the tribometer, at normal force that fits medium load $\left(F_{\mathrm{N}}=0,6 \mathrm{~N}\right)$, under different values of sliding speed $\left(v=3 ; 9\right.$ and $\left.15 \mathrm{mms}^{-1}\right)$.

The results obtained at lower and higher loads were presented within the previous research [20] and can therefore be compared.

Due to the alternating motion of the cantilever of $\mathrm{CSM}^{\circledR}$ tribometer between two end positions, the friction force was changing direction during the test.

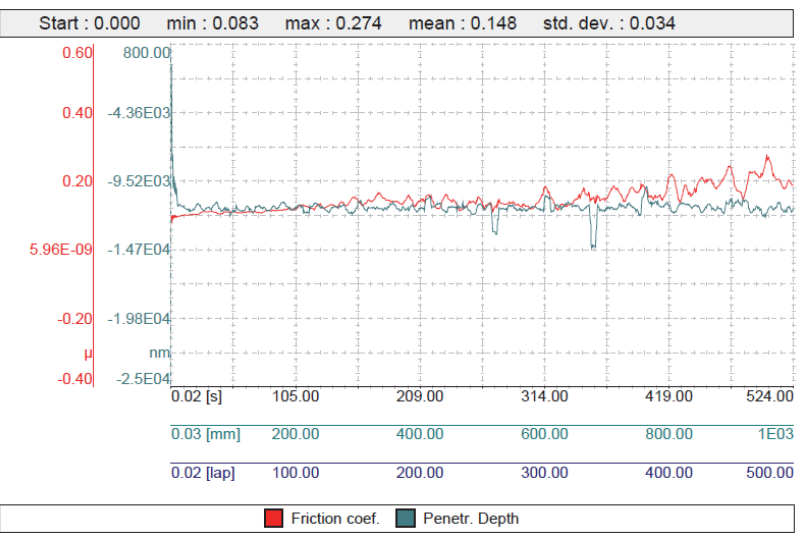

Figure 6 Changes of COF and PD under $\left(F_{\mathrm{N}}=0,6 \mathrm{~N}, v=3 \mathrm{mms}^{-1}\right)$ for base cylinder material (Al-Si) alloy; filtered signal

At lower sliding speed of ball $\left(v=3 \mathrm{mms}^{-1}\right)$, under medium load, COF and PD of base material have relatively approximate values. The values of the COF slightly increase with each cycle. The obtained mean value of the $\mathrm{COF}$ is $(0,148)$, Fig. 6 .

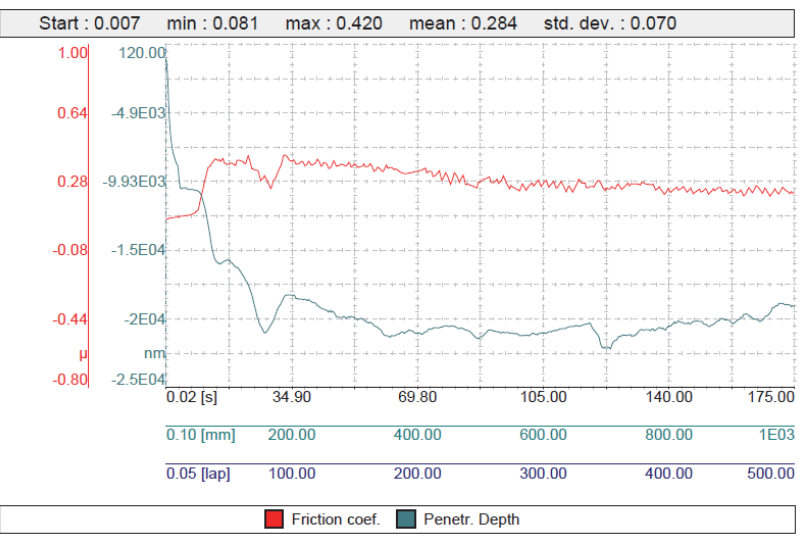

Figure 7 Changes of COF and PD under $\left(F_{\mathrm{N}}=0,6 \mathrm{~N}, v=9 \mathrm{mms}^{-1}\right)$ for base cylinder material (Al-Si) alloy; filtered signal

At higher sliding speeds ( 9 and $15 \mathrm{mms}^{-1}$ ), the COF first increases intensively after the very short running in period and then decreases with low intensity. In both cases, approximate mean values of the $\operatorname{COF}(0,284$ and 0,226$)$ were reached, Fig. 7 and Fig. 8. 


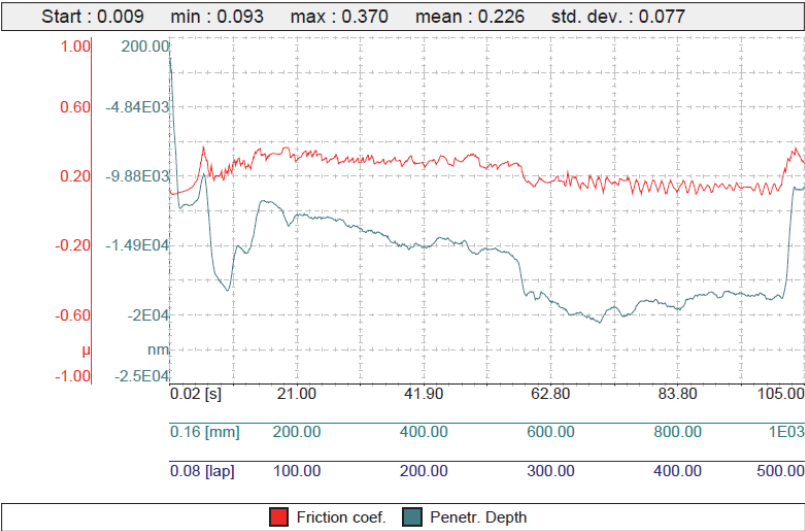

Figure 8 Changes of COF and PD under $\left(F_{\mathrm{N}}=0,6 \mathrm{~N}, v=15 \mathrm{mms}^{-1}\right)$ for base cylinder material (Al-Si) alloy; filtered signal

In case of higher sliding speeds ( 9 and $15 \mathrm{mms}^{-1}$ ) PD values are more intense and variable, as a result of the intensive material transfer process (from sample material to tribometer ball). The transfer of material is due to the fact that the base material (Al-Si) alloy is softer than the material of inserted reinforcements (cast iron) alloy in analyzed cases.

\subsection{Determination of Coefficient of Friction and Penetration Depth of Reinforcements (Cast Iron) Alloy}

When testing material of reinforcements, similar results for mean $\operatorname{COF}(0,238$ and 0,237$)$ were obtained under higher sliding speeds, for same load $\left(F_{\mathrm{N}}=0,6 \mathrm{~N}\right)$ as it was in case of base cylinder material, Fig. 10 and Fig. 11. In this case, the mean value of the $\operatorname{COF}(0,238)$ of the reinforcements at the sliding speed $\left(v=9 \mathrm{mms}^{-1}\right)$ is lower than the comparative value obtained by testing the base material $(0,284)$. The recorded maximum values of the COF $(0,334$ and 0,328$)$ of the reinforcements are lower than the comparative values obtained by testing the base material $(0,420$ and 0,370$)$, Fig. 7 and Fig. 8.

During material testing under lower sliding speed $(v=$ $3 \mathrm{mms}^{-1}$ ), it was unexpectedly recorded a higher mean value of the COF $(0,355)$, Fig. 9, compared to values obtained by testing the base material $(0,148)$.

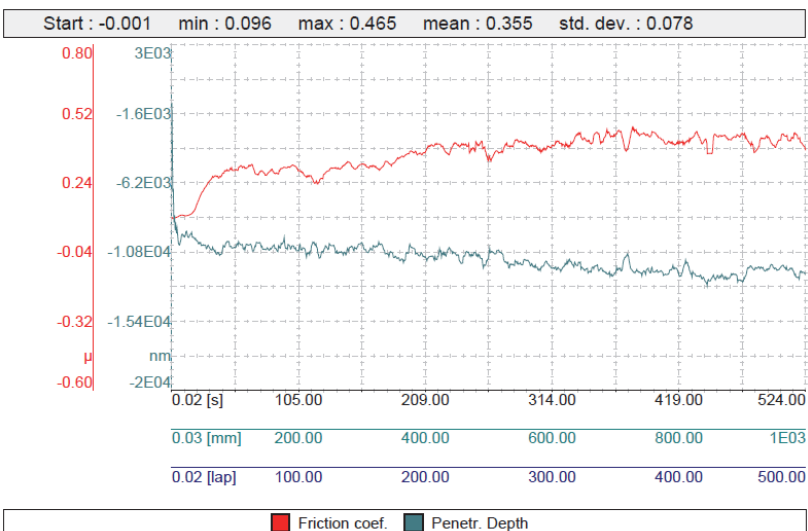

Figure 9 Changes of COF and PD under $\left(F_{\mathrm{N}}=0,6 \mathrm{~N}, v=3 \mathrm{mms}^{-1}\right)$ for cast iron inserts; filtered signal

In all three presented plots, Fig. 9, Fig. 10 and Fig. 11, PD value is almost constant, which is not the case with the base cylinder material, specifically under two higher sliding speeds (Fig. 7 and Fig. 8).

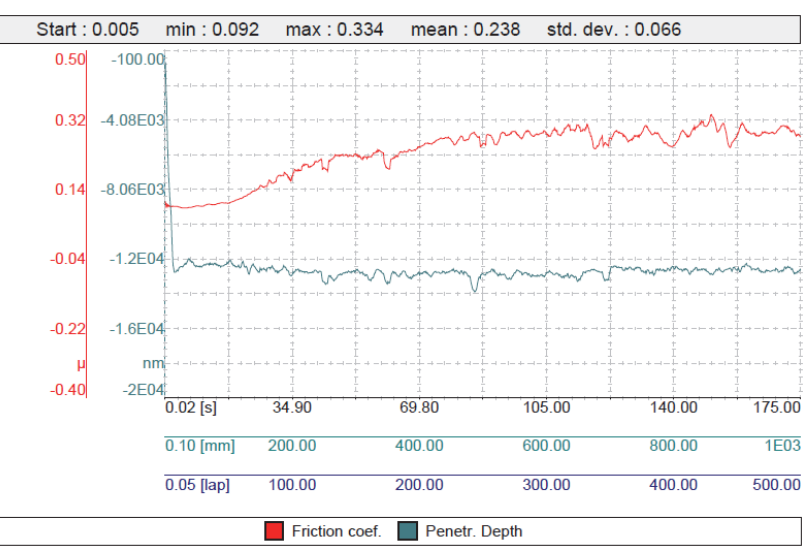

Figure 10 Changes of COF and PD under $\left(F_{\mathrm{N}}=0,6 \mathrm{~N}, v=9 \mathrm{mms}^{-1}\right)$ for cast iron inserts; filtered signal

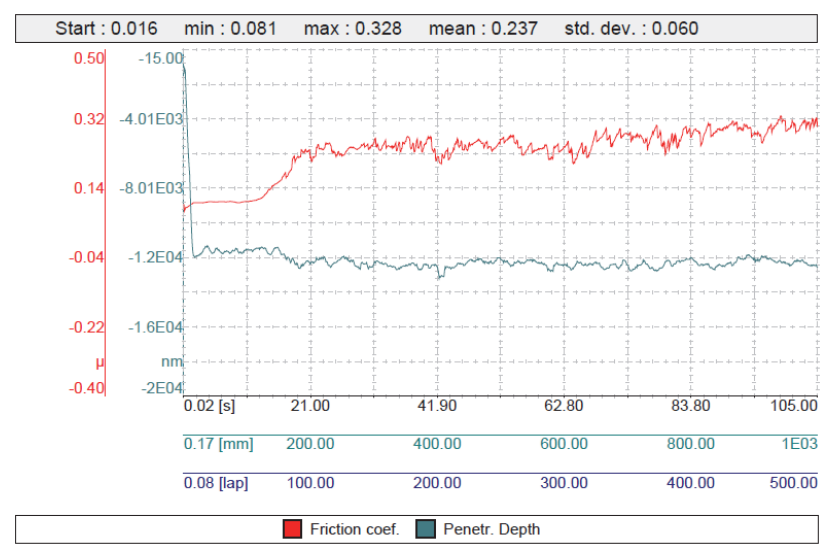

Figure 11 Changes of COF and PD under $\left(F_{\mathrm{N}}=0,6 \mathrm{~N}, v=15 \mathrm{mms}^{-1}\right)$ for cast iron inserts; filtered signal

The main reason is the fact that in the case of cast-iron inserts no material transfer is recorded (Fig. 15, Fig. 16 and Fig. 17). The inserts material is harder than $\mathrm{Al}$ alloy, so that no plastic deformations were occurring on the surfaces in tribology contact. Therefore, the adhesive wear of the material is not present in the case of cast-iron inserts, as is the case with the base cylinder material (Fig. 12, Fig. 13 and Fig. 14). The observed phenomena were explained by a detailed wear track analysis of both contact elements, prepared samples and counter body, 1,5 $\mathrm{mm}$ steel ball.

\section{OPTICAL MICROSCOPIC ANALYSIS OF MATERIAL WEAR PHENOMENA AND DISCUSSION OF RESULTS}

Optical microscopy of obtained wear tracks were presented in Fig. 12, Fig. 13 and Fig. 14 for the base cylinder material (Al-Si) alloy, and Fig. 15, Fig. 16 and Fig. 17 for cast iron inserts.

Based on Fig. 13 and Fig. 14, adhesive wear was recorded mainly due to the presence of material transfer. To confirm mentioned material transfer counter body steel ball surface was analyzed using optical microscope (Fig. 19 and Fig. 20).

Contrary, at lower sliding speed $\left(v=3 \mathrm{mms}^{-1}\right)$ abrasion wear is the most dominant wear mechanism, which results in parallel grooves along with the steel ball sliding direction (Fig. 12) and clean scratches on the steel ball (Fig. 18). It could be assumed that at lower sliding speed critical temperature for adhesion bonding was not achieved. 


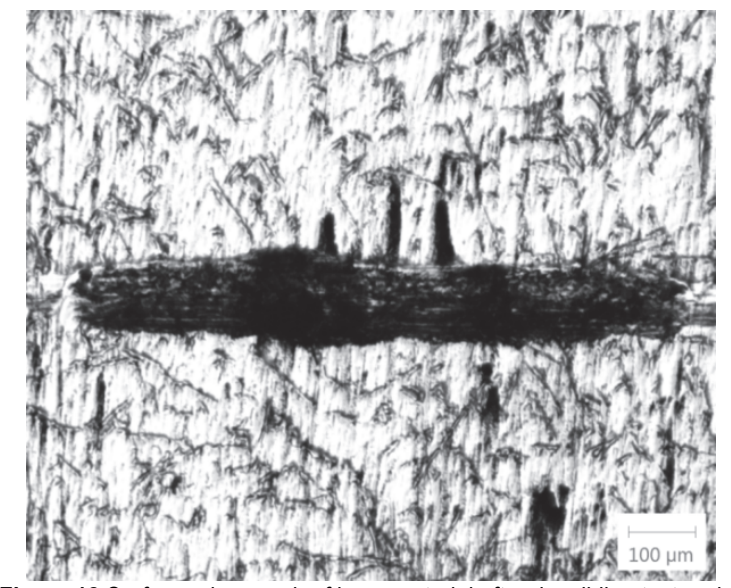

Figure 12 Surface micrograph of base material after dry sliding test under $\left(F_{\mathrm{N}}=0,6 \mathrm{~N}, v=3 \mathrm{mms}^{-1}\right)$

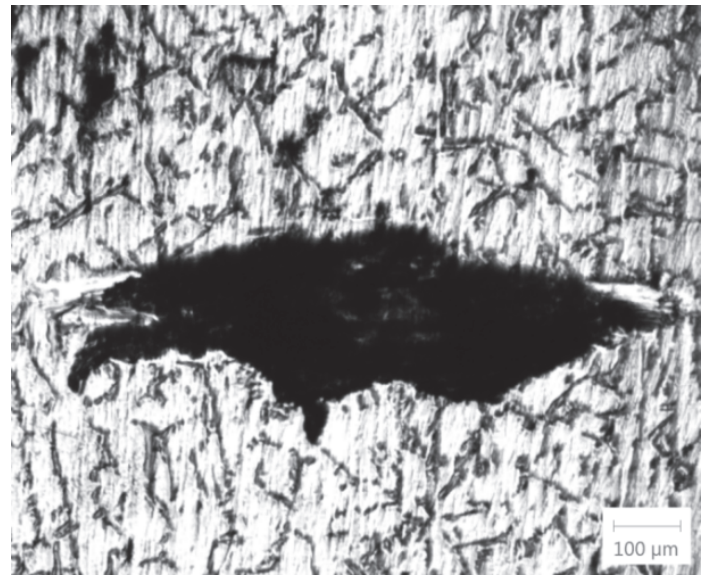

Figure 13 Surface micrograph of base material after dry sliding test under $\left(F_{\mathrm{N}}=0,6 \mathrm{~N}, v=9 \mathrm{mms}^{-1}\right)$

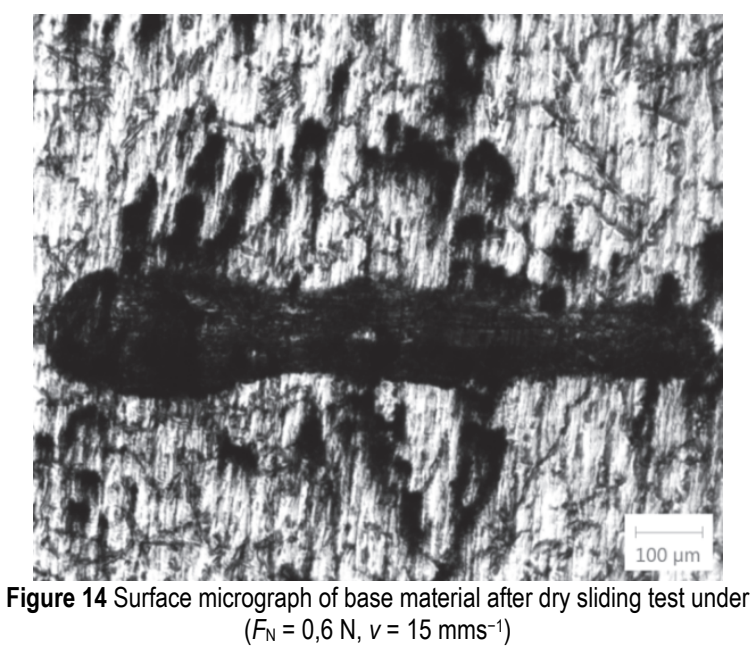

Analyzing the wear traces of the tested materials, it was concluded that the wear of the base cylinder material is significantly higher compared to the wear of the reinforcements.

The abrasive wear is the most dominant wear mechanism for cast iron inserts (Fig. 15, Fig. 16 and Fig. 17) due to contact of two hard surfaces (ball and cast-iron inserts). As a result of that kind of contact small wear debris were generated, that could act as abrasive material if trapped in contact zone. Similar wear tracks, with clean parallel grooves were obtained on the steel ball, (Fig. 21 to Fig. 23).

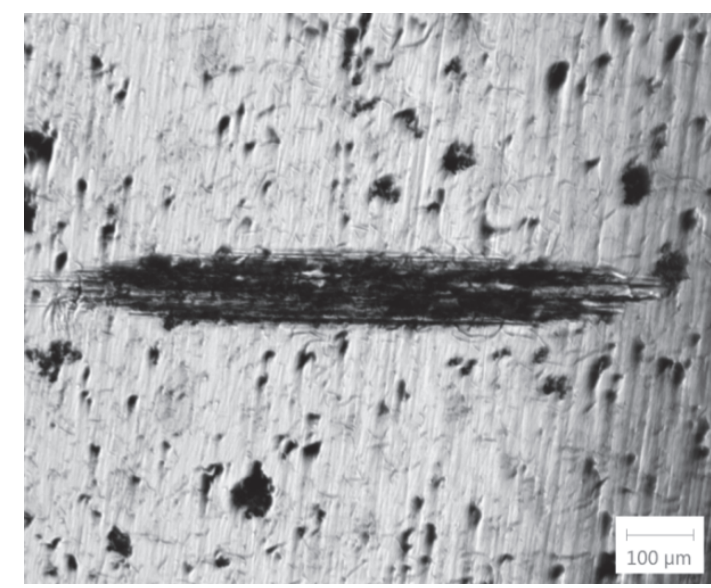

Figure 15 Surface micrograph of reinforcement after dry sliding test under $\left(F_{\mathrm{N}}=0,6 \mathrm{~N}, v=3 \mathrm{mms}^{-1}\right)$
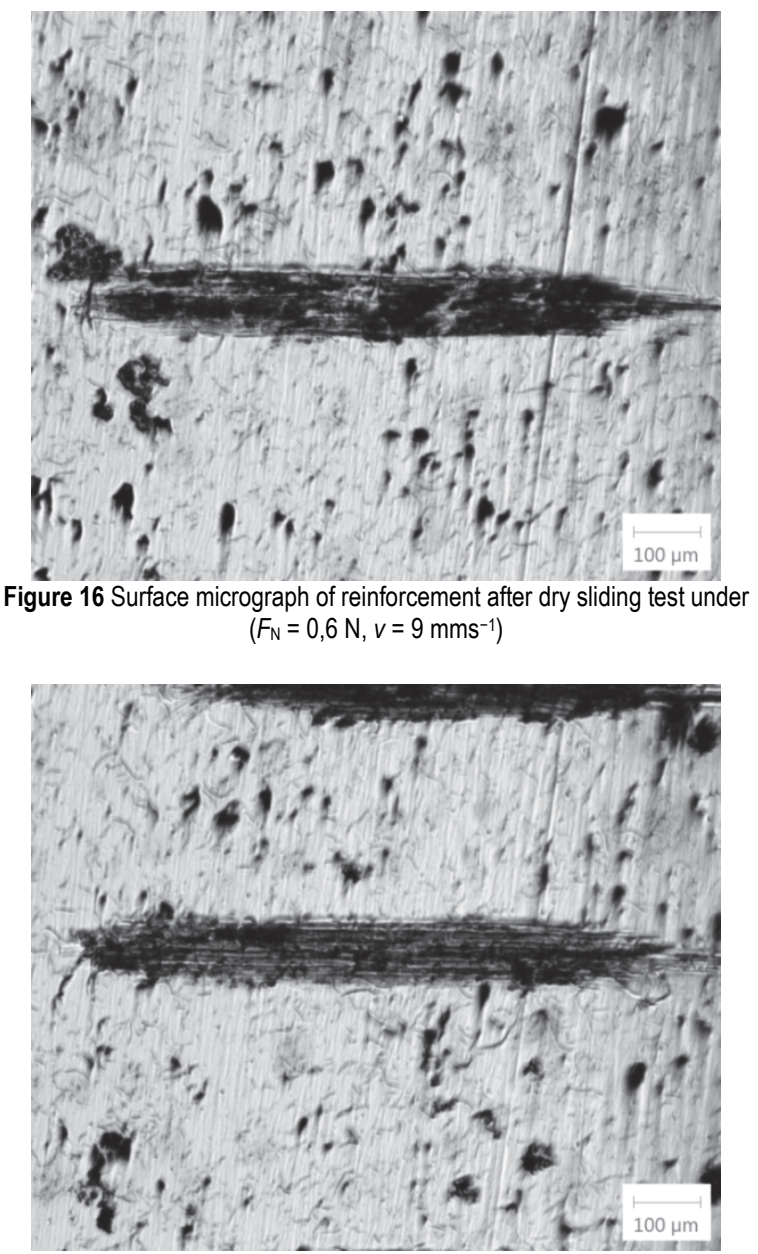

Figure 17 Surface micrograph of reinforcement after dry sliding test under $\left(F_{\mathrm{N}}=0,6 \mathrm{~N}, v=15 \mathrm{mms}^{-1}\right)$

The hardness of both tested materials was determined by standard testing. The average hardness values are $(H V$ $=90)$ for the base cylinder material and $(H V=318)$ for the cast-iron inserts. The average values of the Young modulus were $(E=100 \mathrm{GPa})$ and $(E=155 \mathrm{GPa})$ for base cylinder material and cast-iron inserts, respectively.

The mechanical characterization of the material and the determination of the mechanical properties of the surface layer were performed using CSM Nano Hardness Tester $\left(\mathrm{NHT}^{2}\right)$, with Berkowich diamond indenter [10, 20]. 


\subsection{Wear of Tribometer Ball Surface}

In addition to the above results and explanations, wear tracks of the steel ball will be analyzed.

Analyzing wear track on the steel ball presented in Fig. 18 it could be concluded that there was no visible or intense material transfer on the steel ball surface. Based on that and on obtained PD plot (Fig. 6) and on wear track on tested material it could be concluded that abrasive wear of the material is more dominant.

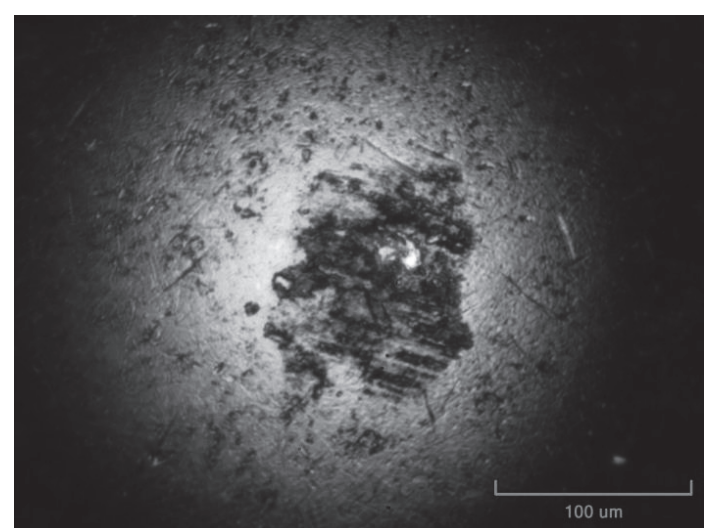

Figure 18 Optical microscopy of the counter body steel ball profile after sliding test of base material (Al-Si) alloy under $\left(F_{\mathrm{N}}=0,6 \mathrm{~N}, v=3 \mathrm{mms}^{-1}\right)$

At higher sliding speeds $\left(v=9\right.$ and $\left.15 \mathrm{mms}^{-1}\right)$, intense material transfer on the ball was recorded, Fig. 19 and Fig. 20. These are clear traces of adhesive wear of the material.

The fact is that after a certain sliding time, material transfer occurs, which is registered in real time by tangential force sensor and sensor for ball movements along the $\mathrm{z}$ axis. As a result of material transfer abrupt change in COF and PD value is registered. From that point sliding contact between tested sample and steel ball becomes the contact of two similar materials (Al-Si alloy as the base cylinder material and the transferred layer on the ball that is by its structure similar to the tested material).

Piling up of transferred material on the steel ball contact surface is registered by penetration depth sensor and presented with adequate PD curves.

Analyzing mentioned PD curves it is obvious that position along the $Z$ axis of steel ball abruptly changes during the sliding process, but not due to its penetration in the tested material. Main reason for this kind of movement is the creation of transferred layer on the ball surface and its degradation when it reaches the critical point in which it is not capable to bear tangential forces.

Along with the material transfer progress, real contact area increases which results in increased wear track width (Fig. 12, Fig. 13 and Fig. 14).

Material transfer was not noticed in case of cast-iron inserts tribological tests. Therefore, there is no trace of adhesive material on the surface of the ball, (Fig. 21, Fig. 22 and Fig. 23). Similar conclusion can be reached according to the photographs of the surfaces of the test material, (Fig. 15, Fig. 16 and Fig. 17). Therefore, the PD curve is almost linear (Fig. 9, Fig. 10 and Fig. 11).

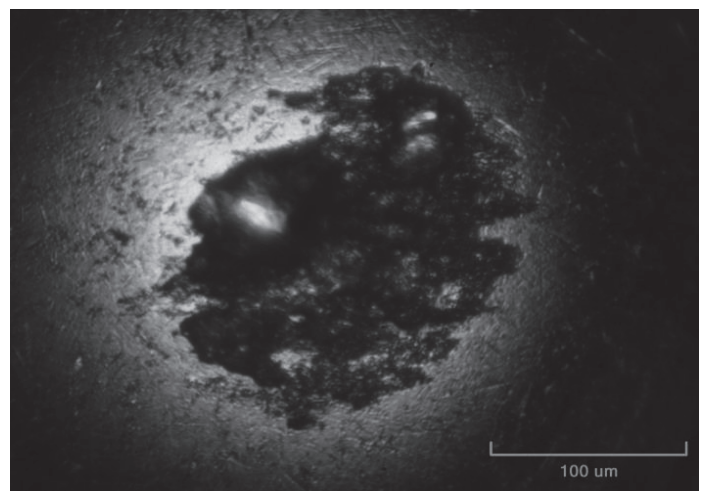

Figure 19 Optical microscopy of the counter body steel ball profile after sliding test of base material (Al-Si) alloy under $\left(F_{\mathrm{N}}=0,6 \mathrm{~N}, v=9 \mathrm{mms}^{-1}\right)$

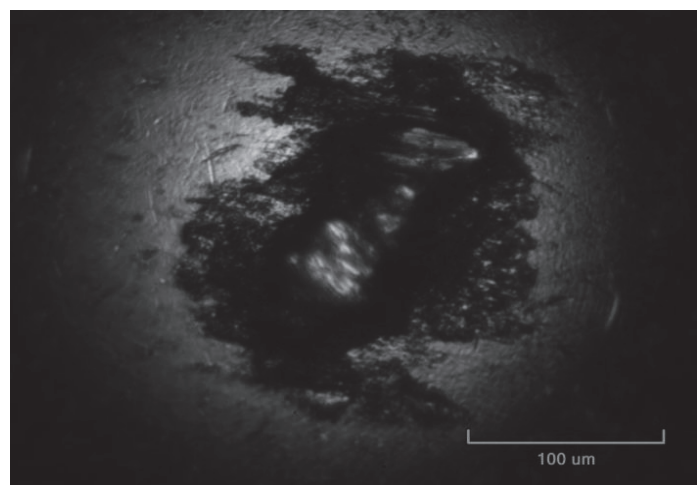

Figure 20 Optical microscopy of the counter body steel ball profile after sliding test of base material (Al-Si) alloy under $\left(F_{\mathrm{N}}=0,6 \mathrm{~N}, v=15 \mathrm{mms}^{-1}\right)$

At the beginning of tribological dry sliding test of cast iron inserts COF increases as a result until the real contact area on both elements is achieved, since at the early beginning contact was made in a few points, due to tribometer contact geometry, (Fig. 9, Fig. 10 and Fig. 11). Similar results can be found in the literature $[39,40]$.

This is consistent with the fact that in the case of reinforcement materials, during sliding friction, the abrasive wear mechanism dominates.

At the beginning of sliding, under lower speed $(v=3$ $\mathrm{mms}^{-1}$ ), the surface parts roughness of both materials is cut off, after that a wear debris was generated in tribological contact. As a result, friction increased and bigger peaks of COF were recorded as well as a meaner value $(0,355)$ than expected, Fig. 9.

For comparison, the mean value of the $\mathrm{COF}$ of the base (softer) material is much lower $(0,148)$ what also was not expected, as explained before, Fig. 6 .

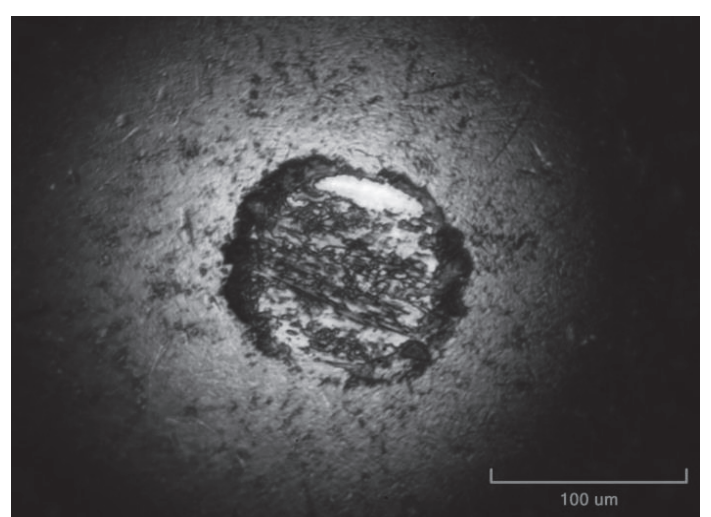

Figure 21 Optical microscopy of the counter body steel ball profile after sliding test of reinforcement (cast iron) alloy under $\left(F_{\mathrm{N}}=0,6 \mathrm{~N}, v=3 \mathrm{mms}^{-1}\right)$ 


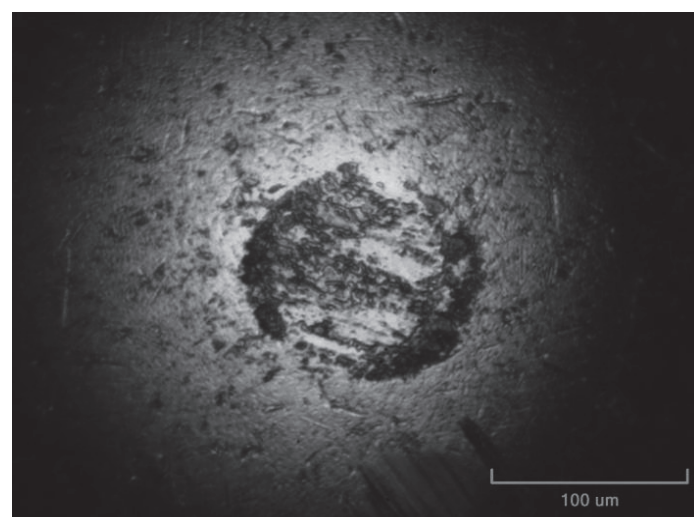

Figure 22 Optical microscopy of the counter body steel ball profile after sliding test of reinforcement (cast iron) alloy under $\left(F_{\mathrm{N}}=0,6 \mathrm{~N}, v=9 \mathrm{mms}^{-1}\right)$

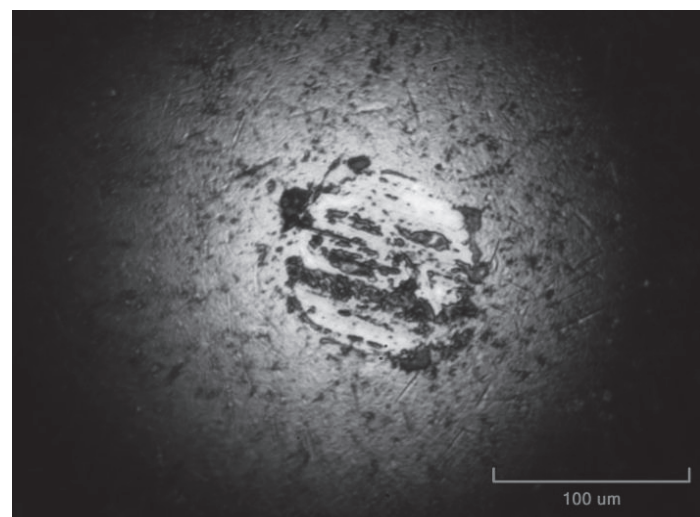

Figure 23 Optical microscopy of the counter body steel ball profile after sliding test of reinforcement (cast iron) alloy under $\left(F_{\mathrm{N}}=0,6 \mathrm{~N}, v=15 \mathrm{mms}^{-1}\right)$

After the first period, the third body is removed from the tribological contact, so that $\mathrm{COF}$ at higher sliding speeds is lower than referent value of the base material under same conditions. This is especially related to recorded maximum values, (Fig. 10 and Fig. 11), and comparative (Fig. 7 and Fig. 8), respectively.

In addition to the previous analyses, the (Fig. 24 and Fig. 25) show a tribometer ball side profile, before and after the testing that confirms previously mentioned statement related to the material transfer on the steel ball surface.

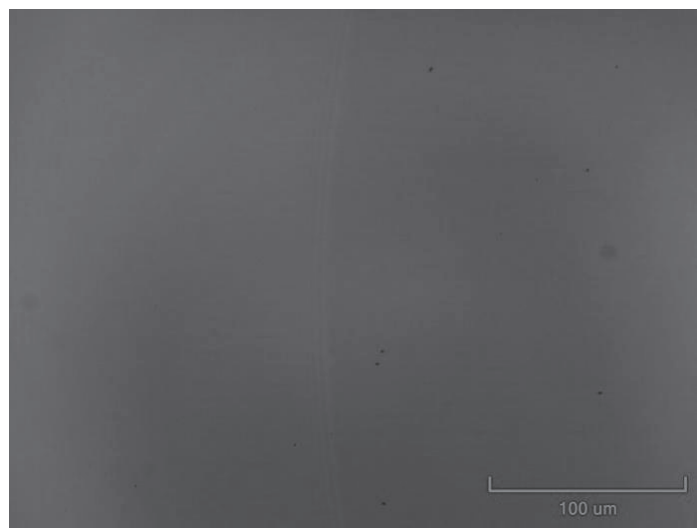

Figure 24 Optical microscopy of the counter body steel ball profile before sliding test (side view)

The test results of researches, under other, higher and lower loads, are similar and could be found in the literature for comparison [20].

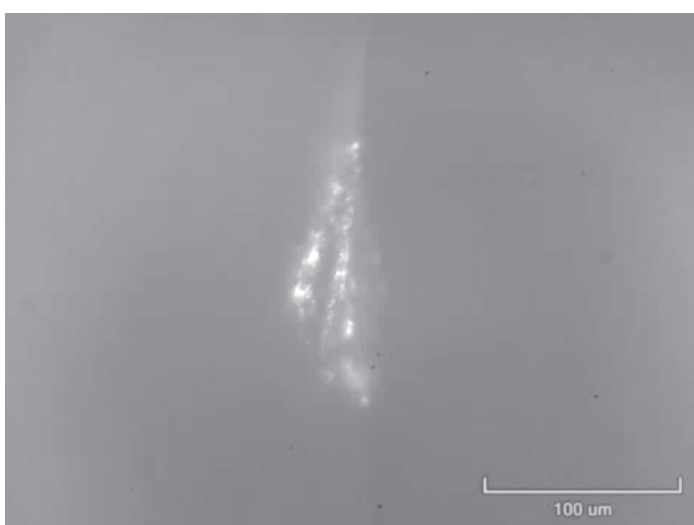

Figure 25 Optical microscopy of the counter body steel ball profile after sliding test against base cylinder material (Al alloy) (side view)

\section{CONCLUSION}

Within the engines and compressors, the relative motion of piston with rings inside the cylinder liner has the largest impact on fuel consumption because of higher friction and wear.

By modification of surfaces which are in the relative or sliding contact, with anti-friction coatings and use of composite materials, we can resolve the problems related to hardness, friction and wear of aluminum parts.

For the purposes of the experiment, partially the surface of the aluminum cylinder as base material (alloy EN AlSil0Mg) was modified and reinforced by inserting tribological reinforcements of cast iron arranged in the form of discrete tribological plugs or spheres (nodule).

When testing the material of cast iron inserts, similar results for mean $\operatorname{COF}(0,238$ and 0,237$)$ were obtained under higher sliding speeds, for the same load $\left(F_{\mathrm{N}}=0,6 \mathrm{~N}\right)$. In this case, the mean value of the $\operatorname{COF}(0,238)$ of the reinforcements at sliding speed $\left(v=9 \mathrm{mms}^{-1}\right)$ was lower than the comparative value obtained by testing the base material $(0,284)$. The recorded maximum values of the COF $(0,334$ and 0,328$)$ of the reinforcements were lower than the comparative values obtained by testing the base material $(0,420$ and 0,370$)$.

During material testing under lower sliding speed $(v=$ $\left.3 \mathrm{mms}^{-1}\right)$, it was unexpectedly recorded a higher mean value of the $\operatorname{COF}(0,355)$, compared to the values obtained by testing the base material $(0,148)$.

The reinforcement material (cast iron) alloy is harder, so that no plastic deformations were occurring on the surfaces in tribology contact. Therefore, the adhesive wear of the material is not present in the case of reinforcements, as is the case with the base material (Al-Si) alloy.

During the test of base material, after a certain sliding time, because of material transfer to the ball surface, at one point started the sliding between two same metals (Al-Si alloy as the base material and the transferred, volume of Al-Si alloy on the ball).

In the case of reinforcement materials, during sliding friction, the abrasive wear mechanism dominates.

\section{Acknowledgements}

The paper is a result of the research within the project TR 35041 financed by the Ministry of Science and Technological Development of the Republic of Serbia. 


\section{REFERENCES}

[1] Alessandro, M., Jelica, P., Biagio, C., Simone, S., \& Georgios, F. (2015).Gaseous Emissions from Light-Duty Vehicles: Moving from NEDC to the New WLTP Test Procedure. Environmental Science \& Technology, 49(14), 8315-8322. https://doi.org/10.1021/acs.est.5b01364

[2] Skrúcaný, T., Kendra, M., Stopka, O., Milojević, S., Figlus, T., \& Csiszár, C. (2019). Impact of the Electric Mobility Implementation on the Greenhouse Gases Production in Central European Countries. Sustainability, 11(18), 4948. https://doi.org/10.3390/su11184948

[3] Jette, K., Christian, T., Dimitrios, T., Zissis, S., Christian, R., Andy, W., Peter, P., Thierry, C., Stephan, N., \& Wim, V. (2020). EU road vehicle energy consumption and CO2 emissions by 2050-Expert-based scenarios. Energy Policy, 138,111224 , ISSN 0301-4215. https://doi.org/10.1016/j.enpol.2019.111224

[4] Osipowicz, T., Abramek, K. F., Barta, D., et al. (2018). Analysis of possibilities to improve environmental operating parametersof modern compression - ignition engines. Advances In Science And Technology-Research Journal. 12(2), 206-213.

[5] Engine Systems, After treatment, Fuels, Lubricants, and Materials." National Academies of Sciences, Engineering, and Medicine. 2015. Review of the 21st Century Truck Partnership: Third Report. Washington, DC: The National Academies Press. https://doi.org/10.17226/21784

[6] Friedl, H., Certic, M., Fuerhapter, A., Kapus, P., Koeck, K., \& Neubauer, M. (2013). Technology Features and Development Methods for Spark Ignited Powertrain to Meet 2020 CO2 Emission Targets. SAE Technical Paper, 201336-0438. https://doi.org/10.4271/2013-36-0438

[7] Ağbulut, Ü., Sarıdemir, S., \& Albayrak, S. (2019). Experimental investigation of combustion, performance and emission characteristics of a diesel engine fuelled with diesel-biodiesel-alcohol blends. J Braz. Soc. Mech. Sci. Eng., 41, 389. https://doi.org/10.1007/s40430-019-1891-8

[8] Cho, I., Lee, Y., \& Lee, J. (2018). Investigation on the Effects of Internal EGR by Variable Exhaust Valve Actuation with Post Injection on Auto-ignited Combustion and Emission Performance. Appl. Sci., 8(4), 597. https://doi.org/10.3390/app8040597

[9] Milojević, S. \& Pešić, R. (2018). Determination of Combustion Process Model Parameters in Diesel Engine with Variable Compression Ratio. Journal of Combustion, 2018, Article ID 5292837. https://doi.org/10.1155/2018/5292837

[10]Skrzek, T., Rucki, M., Gorski, K., Matijošius, J., Barta, D., Caban, J., \& Zarajczyk, J. (2015). Repeatability of HighPressure Measurement in a Diesel Engine Test Bed. Sensors, 20(12).

[11]Luther, R. \& Harperscheid, M. (2016). Multi-talented Motor Oil Conflicting Goals in Friction Reduction. MTZ Worldw 77, 10-15. https://doi.org/10.1007/s38313-016-0140-0

[12]Knauder, C., Allmaier, H., Sander, D. E., \& Sams, T. (2020). Investigations of the Friction Losses of Different Engine Concepts: Part 3: Friction Reduction Potentials and Risk Assessment at the Sub-Assembly Level. Lubricants, 8(4), 39. https://doi.org/10.3390/lubricants 8040039

[13]Holmberg, K. \& Erdemir, A. (2017). Influence of tribology on global energy consumption, costs and emissions. Friction, 5, 263-284. https://doi.org/10.1007/s40544-017-0183-5

[14]Ba, L., He, Z., Guo, L., Chiang, Y., Zhang, G., \& Lu, X. (2015). Piston ring-cylinder liner tribology investigation in mixed lubrication regime: part I-correlation with bench experiment. Industrial Lubrication and Tribology, 67(6), 520-530. https://doi.org/10.1108/lLT-07-2013-0078

[15] Kadirgama, K., Ramasamy, D., El-Hossein, K. A., Hwa, K. C., \& Kadirgama, G. (2017). Assessment of alternative methods of preparing internal combustion engine cylinder bore surfaces for frictional improvement. J Braz. Soc. Mech. Sci. Eng., 39, 3591-3605. https://doi.org/10.1007/s40430-017-0789-6

[16]Kulkarni, S., Edwards, D., Parn, E., Chapman, C., Aigbavboa, C., \& Cornish, R. (2018). Evaluation of vehicle light weighting to reduce greenhouse gas emissions with focus on magnesium substitution. Journal of Engineering, Design and Technology, 16(6), 869-888. https://doi.org/10.1108/JEDT-03-2018-0042

[17]Wenlong, S., Xiaokai, C., \& Lu, W. (2016). Analysis of Energy Saving and Emission Reduction of Vehicles Using Light Weight Materials. Energy Procedia. 88. 889-893. https://doi.org/10.1016/j.egypro.2016.06.106

[18]Milojević, S. \& Stojanović, B. (2018). Determination of tribological properties of aluminum cylinder by application of Taguchi method and ANN-based model. J Braz. Soc. Mech. Sci. Eng., 40, 571. https://doi.org/10.1007/s40430-018-1495-8

[19]Veličković, S., Stojanović, B., Ivanović, L., Miladinović, S., \& Milojević, S. (2019). Application of Nanocomposites in the Automotive Industry. Mobility \& Vehicle Mechanics (MVM), 45(4), 51-64. https://doi.org/10.24874/mvm.2019.45.03.05

[20]Milojević, S., Džunić, D., Taranović, D., Pešić, R., \& Mitrović, S. (2017). Tribological Reinforcements for Cylinder Liner of Aluminum-Example Compressors for Brake Systems of Trucks and Buses. 15th International Conference on Tribology SERBIATRIB '17, Kragujevac, 2017, 17 -19 May, 251-257.

[21]Du, F., Li, C., Mi, Z., Huang, R., Han, X., Shen, Y., \& Xu, J. (2019). Friction Performance of Aluminum-Silicon Alloy Cylinder Liner after Chemical Etching and Laser Finishing. Metals, 9, 431.https://doi.org/10.3390/met9040431

[22] Zhang, Z., Liu, J., Wu, T., \& Youbai, X. (2017). Effect of carbon nanotubes on friction and wear of a piston ring and cylinder liner system under dry and lubricated conditions. Friction, 147-154. https://doi.org/10.1007/s40544-016-0126-6

[23]Zabala, B., Igartua, A., Fernández, X., Priestner, C., Ofner, H., Knaus, O., Abramczuk, M., Tribotte, P., Girot, F., Román, E., \& Nevshupa, R. (2016). Friction and wear of a piston ring/cylinder liner at the top dead centre: Experimental study and modelling. Tribology International, 106. https://doi.org/10.1016/j.triboint.2016.10.005

[24]Akbarzadeh, A. \& Khonsari, M. M. (2018). Effect of Untampered Plasma Coating and Surface Texturing on Friction and Running-in Behavior of Piston Rings. Coatings, 8, 110. https://doi.org/10.3390/coatings 8030110

[25]Grabon, W., Pawlus, P., Wos, S., Koszela, W., \& Wieczorowski, M. (2016). Effects of honed cylinder liner surface texture on tribological properties of piston ring-liner assembly in short time tests. Tribology International. https://doi.org/10.1016/j.triboint.2016.11.025

[26]Sasaki, S. (2010). Environmentally friendly tribology (Ecotribology). J MechSciTechnol24, 67-71. https://doi.org/10.1007/s12206-009-1154-1

[27]Ahmed Ali, M. K., Xianjun, H., Fiifi, T. R., \& Ezzat, M. (2016). An analytical study of tribological parameters between piston ring and cylinder liner in internal combustion engines. Proceedings of the Institution of Mechanical Engineers, Part K: Journal of Multi-Body Dynamics, 230(4), 329-349. https://doi.org/10.1177/1464419315605922

[28]Meiser, J., Deuß, T., Ehnis, H., \& Kunzel, R. (2017). Friction Power Measurements of a Fired Gasoline Engine Influence of Piston Pin Bore. MTZ Worldw, 78, 58-62. 
https://doi.org/10.1007/s38313-016-0152-9

[29]Allmaier, H., Knauder, C., Sanders, D., \& Reich, F.(2016). Combination of Measurement and Simulation to Analyse Engine Friction. MTZ Worldw, 77, 66-71. https://doi.org/10.1007/s38313-016-0095-1

[30]Knauder, C., Allmaier, H., Sander, D. E., \& Sams, T. (2019). Investigations of the Friction Losses of Different Engine Concepts. Part 1: A Combined Approach for Applying Subassembly-Resolved Friction Loss Analysis on a Modern Passenger-Car Diesel Engine. Lubricants, 7(39). https://doi.org/10.3390/lubricants7050039

[31]Vencl, A. \& Rac, A. (2004). New wear resistant Al based materials and their application in automotive industry. Mobility \& Vehicle Mechanics (MVM), 30, Special Edition, 2004, 115-139.

[32]Morawitz, U., Mehring, J., \& Schramm, L. (2013). Benefits of Thermal Spray Coatings in Internal Combustion Engines, with Specific View on Friction Reduction and Thermal Management.SAE Technical Paper 2013-01-0292, 2013. https://doi.org/10.4271/2013-01-0292

[33]Banerji, A., Lukitsch, M., McClory, B., White, D. R., \& Alpas, A. T. (2017). Effect of iron oxides on sliding friction of thermally sprayed 1010 steel coated cylinder bores. Wear, 376-377. 858-868. https://doi.org/10.1016/j.wear.2017.02.032

[34]Chao, C. (2017). Power Cylinder System for Internal Combustion Engines, Improvement Trends for Internal Combustion Engines, Bilge Albayrak Ceper and MelihYildiz. Intech Open. https://doi.org/10.5772/intechopen.69762

[35]MAHLE GmbH (2016). Piston design guidelines. In: MAHLE GmbH (eds) Pistons and engine testing. ATZ/MTZ-Fachbuch. Springer Vieweg, Wiesbaden. https://doi.org/10.1007/978-3-658-09941-1_2

[36]Makhlouf, M. M. \& Guthy, H. V. (2001). The aluminumsilicon eutectic reaction: mechanisms and crystallography. Journal of Light Metals, 1(4), 199-218. https://doi.org/10.1016/S1471-5317(02)00003-2

[37]Wang, Q. G., Caceres, C. H., \& Griffiths, J. R. (2003). Damage by eutectic particle cracking in aluminum casting alloys A356/357. Metall and Mat Trans A, 34, 2901-2912. https://doi.org/10.1007/s11661-003-0190-1

[38]Theuwissen, K., Lacaze, J., \& Laffont, L. (2016). Structure of graphite precipitates in cast iron. Carbon, 96, 1120-1128. https://doi.org/10.1016/j.carbon.2015.10.066

[39] Omrani, E., Moghadam, A. D., Menezes, P. L., \& Rohatgi, P. K. (2016). Influences of graphite reinforcement on the tribological properties of self-lubricating aluminum matrix composites for green tribology, sustainability, and energy efficiency-a review. Int $J$ Adv Manuf Technol, 83, 325-346. https://doi.org/10.1007/s00170-015-7528-x

[40]Sun, G., Bhattacharya, S., White, D. R., \& Alpas, A. T. (2018). Indentation Fracture Behavior of Low Carbon Steel Thermal Spray Coatings: Role of Dry Sliding-Induced. Tribolayer. J Therm Spray Tech, 27, 1602-1614. https://doi.org/10.1007/s11666-018-0799-7

\section{Contact information:}

Saša MILOJEVIĆ, expert advisor

(Corresponding author)

University of Kragujevac, Faculty of Engineering,

Department for Motor Vehicles and Engines

Sebia, Kragujevac 34000, Sestre Janjić 6

E-mail: sasa.milojevic@kg.ac.rs

Dragan DŽUNIĆ, assoc. prof.

University of Kragujevac, Faculty of Engineering,

Department for Production Engineering,

Sebia, Kragujevac 34000, Sestre Janjić 6

E-mail: dzuna@kg.ac.rs

\section{Dejan MARIĆ, PhD}

(Corresponding author)

University of Slavonski Brod,

Mechanical Engineering Faculty in Slavonski Brod,

Trg Ivane Brlic Mazuranic 2, HR-35000 Slavonski Brod, Croatia

E-mail: dmaric@unisb.hr

Tomáš SKRÚCANÝ, prof.

University of Žilina, Faculty of operation and economics of transport and communications,

Department of road and urban transport,

Slovakia, Žilina 010 26, Univerzitná 8215/1

E-mail: tomas.skrucany@fpedas.uniza.sk

Slobodan MITROVIĆ, prof.

University of Kragujevac, Faculty of Engineering,

Department for Production Engineering,

Sebia, Kragujevac 34000, Sestre Janjić 6

E-mail: boban@kg.ac.rs

Radivoje PEŠı́́, prof.

University of Kragujevac, Faculty of Engineering,

Department for Motor Vehicles and Engines,

Sebia, Kragujevac 34000, Sestre Janjić 6

E-mail: pesicr@kg.ac.rs 